Oral Tradition, 25/2 (2010): 283-303

\title{
"Writing" and "Reference" in Ifá Divination Chants
}

\section{Adélékè Adéẹkọo}

In July 1897, Bishop C. Phillips, a leading member of the Yorùbá-speaking clergy of the Anglican Church in Nigeria, praised Rev. E. M. Lijadu's commentaries on Ifá divination stories as a bold first step towards understanding the basis of the disappointing result of evangelization in the Yorùbá missionary field. Thinking of conversion work in warfare terms, Bishop Phillips believed Lijadu's collection and commentary to be a brilliant reconnaissance (Lijadu 1898:4):

Bí a kò bá rí ìdí ibi tí agbára ọ̀tá gbé wà, a kò lè șegun wọn. Bí àwa Kristian kò bá mọ ìdí ìsìn àwọn Kèfèrí àti àwọn Ìmàle, a kì yóò lè gbé ìhìnrere Kristi síwájú wọn lí ọ̀nà tí yóò fi ká wọn lára.

If we do not locate the source of our enemies' strength, we cannot defeat them. If we Christians do not fathom the foundation of pagan and Islamic devotion, we will not be able to present Christ's gospel to them in its most appealing form.

The bishop also decried the unfortunate attitude that misled Christian missionaries in Yorùbáspeaking regions to forget how the mastery of pre-Christian practices helped conversion in biblical places and times. ${ }^{1}$ For not acting early enough on pre-Christian Yorùbá religion, Bishop Phillips rebukes fellow soldiers for their intellectual arrogance and judges unconscionable their belief that they could effectively preach and convert without understanding the thought basis among the people whom they are charged with persuading about the Gospel (idem):

Șùgbớn àwa ńja ogun àti-fi ìhìnrere Kristi múlẹ ni ilẹ wa láì wá ìdí ìsìn àtọwộdộoó àwọn bàbá wa tí ó ní agbára tóbeẹe lórí àwọn Kèfèrí. Nítorí náà ni ìwàásù wa kò ní agbára tó bẹeè lórí wọn. Òmíràn nínú wọn rò pé àìmọ̀ ni ó jẹ kí àwa máa sọ ìsọkúsọ sí ìsìn wọn.

We strive to plant Christ's gospel in our country without researching the very strong, albeit pagan, ancient beliefs of our fathers. For that reason our preaching produces little impact. Unknown numbers among them believe that we deride their religions because we know nothing about them.

${ }^{1}$ His examples include Paul's learning Jewish traditions under Gamaliel and his studying Greek idolatry at Tarsus. Bishop Phillips also attributes Moses' success in the Exodus to his intimate knowledge of Egyptian religions. 
Perhaps the most important observation Bishop Phillips made in that short preface concerns the effect that publishing Ifá divination stories in book form would have on unbelievers (idem):

\footnotetext{
Nígbà tí àwọn tí ó ńkọ́ Ifá sórí bá mọ̀ pé wớn lè ka Odù Ifá nínú ìwé, mo rò pé yóò șí wọn lórí láti kọ́ ìwé kíkà, àti láti fi ò̀ọ̀ inú Bíbélì wé ti Odù Ifá. Wọn yóò sì rí èyí tí ó sàn jù fún ara wọn.
}

I believe that when rote learners of Ifá stories discover that they can read the Odù in a book, they will seek literacy eagerly, gain the capacity to compare the Bible with Ifá stories, and discover on their own the merit of the superior text.

By casting Ifá stories in a relatively permanent medium, Christian missionaries would be creating a self-reflection apparatus for the literate nonbeliever with which to critically examine the spheres of thought hitherto controlled by the guild of divination priests, the babaláwo. Taking divination stories to be Ifá's main tool of mind control, Bishop Phillips recommended print dissemination of these narratives as a means of freeing the critical faculty of non-Christians from the shroud of secrecy (awo) with which Ifá priests deceived Yorùbá people through the ages. Print technology, he thought, would separate mystery (awo) from its curators (babaláwo). For Bishop Phillips, the deep secret of pre-Christian Yorùbá worship lay not in sculptured icons but in the reasoning that inspired divination stories. If the stories were converted to portable packages comparable to the Bible, the only book authored by the true God, then the theological errors of Yorùbá religion could be easily pointed out. In a palpable, scripted shape, indigenous religious thought could be quoted, disputed, and exposed.

Within Bishop Phillips' manifest desire to accelerate conversion through a literacy campaign sits a noticeable "nationalist" displeasure at the condescension of fellow missionaries who mistook the historical lack of printed scriptures among the Yorùbá as a sign of backwardness (idem):

àwá fi ojú kékeré wo àwọn kèfèrí ilẹ wa nítorí pé wọn kò ní ìwé. Bẹẹ ni àwa mọ̀ pé ó ní iye ẹ̀kọ́ tí ènìyàn ńkọ́ kí a tó gbàá bí babaláwo. Èdè Ifá jinlẹ gidigidi.

We belittle the intelligence of the pagans of our country because they do not have written scriptures, when the situation shows that babaláwo training involves truly extended and rigorous training. Ifá discourse is very profound.

Bishop Phillips seems to insinuate that if the situation were to be considered without prejudice, the unbelievers of "our land" have authored "books" waiting to be transcribed and analyzed. Although his essay stops short of saying that Ifá stories constitute a book, my characterization in this paper of Ifá discourse as devolving around writing shares Bishop Phillips' representation of the storytelling elements of Ifá divination infrastructure as an instituted, durable signification system. $^{2}$

\footnotetext{
2 Those are the terms Jacques Derrida uses to describe general writing in Of Grammatology (1976).
} 
Bishop Phillips isolated two questions that persist in academic studies of Ifá: (1) Does the divination system, especially the contents of the stories, elaborate a unified Yorùbá theological or philosophical viewpoint? and, (2) Are Ifá divination stories oracular utterances or fancy-driven poetic inventions? These questions reflect the concerns of two tendencies in Ifá studies: from the inside, professional custodians of Ifá divination stories, leaning heavily on literal assertions of the stories, claim divine origins for the narratives to warrant proclamations on the nature of all things and ideas - including ideas and thoughts about things and ideas - across time and space; from the outside, the radical polytheism of religious identification in traditional Yorùbárùbá societies encourages skeptics to suspect Ifá's exclusive arrogation of theological centrality to itself.

As Karin Barber's recent study (1990) implies, scholars make Ifá the central divinity in Yorùbá religion because they too easily accept Ifá's own elaborate self-justifications, particularly its stories about itself. Scholars and diviners speak as if the illustrative stories used in Ifá consultation are patently guileless and therefore their divine authorship ascertained. Wánde Abímbólá's (1977:1) report of his informants' belief that the first-hand knowledge the divination God, Òrúnmìnà, gained by virtue of his presence at creation is the source of the disclosure system he supervises during divination, illustrates Barber's point very well. In Abímbólá's accounts, Ifá's divination procedures are retrieval mechanisms that access the corpus of primordial knowledge stored in (and as) divination stories. He asserts, for example, that "Ifá was put in charge of divination because of his great wisdom which he acquired as a result of his presence by the side of the Almighty when the latter created the universe. Ifá therefore knew all the hidden secrets of the universe. Hence, his praise-name Akéréfinúsogobón (the small one who is full of wisdom)" (1977:1). Although he does not trust the truth claims of Ifá's self-justifying narratives, Rev. Lijadu, like Abímbọlá, does not question Ifá's centrality, even in the largely antagonistic first volume of his studies. Lijadu contests the theological basis of many stories, but accepts the placement of Òrúnmìlà next to the Almighty (1898:17-18):

àwọn bàbá wa mọ̀, wọ́n sí ní ìmọ̀ náà lí èrò nígbà gbogbo, wọn kò sì șe tàbítàbí kí wọ́n tó jệoọ ìmọ̀ yìi pé Enni kan ḿbẹ tí í șe Elệdàá ohun gbogbo, tí í șe Olúwa ohun gbogbo, tí ó sì ní ipa, olá àti agbára gbogbo, Olúwa rẹ̀ náà ni wọ́n ńpè lí Qlọ́run Olódùmarè tàbí Qba ơrun [. . .] Olódùmarè ti fi Enni kan șe ibìkejì ara Rẹ̀, Òun à sì máa pe Olúwa rẹ̀ sí ìmọ̀ nínú ohun gbogbo, Òun á sì máa fi ohun gbogbo hàn án, Òun sì fí i șe ẹlẹrìi ara Rẹ ninu ohun gbogbo, tóbeẹè tí kò sí ohun tí Olódùmarè mọ̀ tí Olúwa rẹ̀ náà kò mọ̀, kò sì sí ohun tí Olódùmarè rí tí Òun kò rí. Ẹni náà ni wọ́n ńpè ní “Òrúnmìlà, Elệrìi ìpín, ibìkejì Olódùmarè.” Lộdọ ẹni yìí nìkan ni wớn sì gbàgbó pé ènìyàn lè gbó òdodo ohùn ẹnu àti ìfẹ inú Olódùmarè.

Our forefathers knew, always had the knowledge in them, and did not waiver in witnessing that there is a Being by whom all things were made, the Lord whose might, glory, and power surpass all. That Being they named as God Almighty or Heavenly King [. . . ] God has by his side a second entity to whom he discloses the knowledge of all things and in whom he reposes all confidence such that everything the Almighty knows this person knows, and everything the Almighty sees, he too sees. This person is the one called "Òrúnmìlà, the witness to the allotment of destiny, second to the Almighty." This person is the only true source of Almighty God's plans. 
Although professional interests could have caused the preferment of Abímbọlá's informants, the admiration of indigenous Christian missionaries like Phillips and Lijadu for the promise that Ifá stories hold for systematizing Yorùbá theology suggests that more than selfish goals are involved in the way Ifá is understood. ${ }^{3}$

While I do not share the prosecutorial inclination of Barber's essay, I am sympathetic to her materialist, text-oriented analysis of the incorporation mechanisms with which Ifá discourse presents - definitely not disguises - its operations as unquestionably pantheistic. I propose in this paper that Ifá divination discourse holds the attention of its purveyors because it emphasizes an objective, graphematic approach to constituting intellectual problems, methods of analysis, and means of teasing out solutions. I begin with a brief explication of the divination processes, the underlying reasoning, and the general problems of inquiry that the system raises. My ensuing analysis of the relationship of storytelling to inscriptions shows that the referential relationship between these two main elements of the Ifá divination system is the location from which practitioners derive their authority for creating narrative motifs and commentary-making. The article concludes with a discussion of how the same referential gap enables a view of time that allows divination clients to manage a coherent relationship to the past, the ostensible source of the solutions to their contemporary problems.

\section{Writing in Ifá}

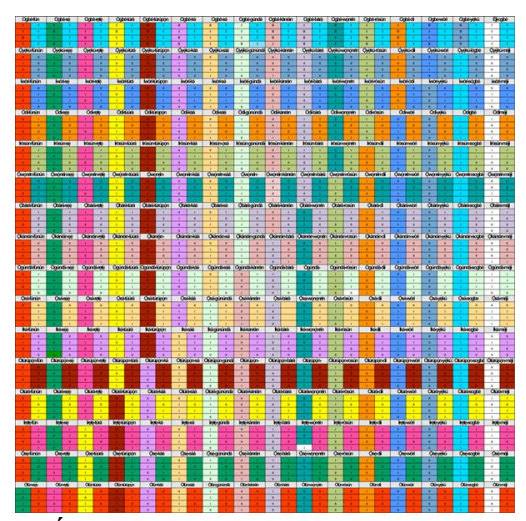

IFÁ Divination "Writing" chart (click image above for fullresolution version)

The foundation of analysis in Ifá is a systematized graphic translation of the results of the random presentation of the divination objects, among which the chain (òpèlè) and palm nuts ( $i$ kin) are the most prestigious. To divine with nuts, the priest holds sixteen ritually sanctified palm nuts in his or her palms, shakes them well, and takes out a bunch with the right hand. If two nuts remain in the left palm, the diviner makes one short vertical fingertip imprint on the fine sand spread out on the divination tray. If one nut remains, two imprints are made. If more than two or none remain, no sign is imprinted. When a chain of eight, hollowed, half divination nut shells, attached four each to two sides of a string is the preferred instrument, the divination process is a little different. The diviner holds up the string and then drops it on the small divination space in front of him or her. The presentation of each throw is transcribed on the tray. A nut that falls with its "concave inner surface upward" indicates two imprints; one that falls with the convex side up indicates one imprint. Producing readable inscriptions is obviously faster with the chain method. In either method the priest reads the imprints, top down, right side first, to identify which of the sixteen basic units of Ifá graphemes (odù ifá) is presented. Identifying the units clues the diviner as to which stories to tell to illustrate the problems revealed by the divination God, and to

\footnotetext{
${ }^{3}$ Rev. James Johnson (1899:19) declares Ifá to be "the great Oracle of the Yorùbá country."
} 
decipher what ritual sacrifices or behavioral changes to prescribe. The casting, imprinting, and narrating process typically starts after the client has whispered his or her purpose into some tokens, which could be money, mixed up with the divination objects. The sign revealed and the illustrative stories told must bear some allegorical semblance to the problems the client wants to solve.

Virtually all Ifá scholars agree on the names, visible appearance, and order of the characters that make up the basic notation system (the graphemes): Ogbè is in the first position, Òyẹkú in the second, and Òfún in the sixteenth. In practical counseling, the basic units must double to produce a diagnosis and/or prognosis. A pattern that signals Òyẹkú on the right and Ogbè on the left is named Òyẹkúlógbè - it is Ogbèyèkú, if the other way round - and one that shows Òfún on both sides is Òfún Méjì (Doubled Òfún). ${ }^{4}$ The inscriptions issue from a grid that is systematically structured so that naming errors can be fixed with little effort. ${ }^{5}$

The foundational role of the inscription system in Ifá divination distinguishes it as a "literate" learned means of inquiry-Ifá is commonly called alákòwé, the scribe or literate oneand not a seance or other kind of intuitive, magical, or "gifted" fortune telling. The practitioners' lengthy and rigorous training further enhances Ifá's image of honest dedication and discipline. References to the profession in everyday speech extol honesty and straightforwardness. The saying "a kìi șawo ká purọ"” ("the person sworn to the divination profession cannot lie") attests axiomatically to the diviner's truthfulness. Of course, professional practices and rituals lend the inscription system an air of mystery, if not mysticism. To the untrained observer, the link between palm nut manipulation (or string casting) and readable, visible imprints is thoroughly occultic. Nonetheless, the credit for that aura belongs largely to the consistent association of named, visibly embodied signs with oracular revelations in the discourse. Diviners gain respect and command attention because they operate as disinterested agents of a disclosure system anchored in an inscription sign system whose production is outwardly indifferent to the "writer's" time- and space-bound will. The mute sign's lack of passion, one way or the other, about the case presented and its theoretical ability to repeat consistently the same signification for all clients cannot but induce trust. The notation system, in theory and perception, removes the individual priest's influence and will from the intercourse between the client and the witness to creation, Òrúnmìlà, who inspirits Òrúnmìlà's knowledge in the presentation of the material divination instrument. The notation system, not the human diviner, arbitrates the most important steps in the discovery and disclosure processes. When diviners, including the most accomplished, attribute their acumen for making correct findings to Ifá- the formula is "Ifá ló wí bẹẹ" ("Ifá renders it thus") — I do not believe humility motivates them; they are touting the superiority of their instruments of discovery.

\footnotetext{
${ }^{4}$ For details of the inscription of process, see Bascom 1969:13-12 and 49-59; Abímbólá 1977:9-11. Afolabi Epega's practitioner manual (1987:7-38) lists by name and visual illustrations all the 256 possible units in the system, from Ejiogbé to Ofúns èé.

${ }^{5}$ For example, an obvious typographical mistake in Abímbólá 1977 records similar graphic marks for both İròsùn (the fifth basic unit) and Obàrà (the seventh). An attentive reader, without being a trained babaláwo, can correct the mistake simply by following the order of twos and ones. See also Bascom 1961 for a discussion of the principles that can be used to correct variations.
} 
Lijadu's work offers evidence of the importance of "writing" to Ifá's prestige. Although his Christian calling demands that he reject Ifá as idolatry — which he does-Lijadu initiates his Ifá studies because the discourse involves a large body of etiological stories. The stories are tied to an inscription system presumed to have originated with a deity believed to have been physically present at the formation of all recognizable things. In Ifá discourse, the genealogy of human problems, after passing through the Divination God and the system of honest inscriptions instituted in his name, goes directly to the Almighty. In the second chapter of Ifá (1898:30), Lijadu asks, "Kínni a lè pè ní İfihàn-Òrò Qlớrun? Kí sì ni èrí tí a lè fi mọ ó yàtò sí ò̀ọ̀ míràn?" ("What is a divine revelation? And what proof distinguishes it from others?") He answers the question thus: "Òrọ̀ Qlọ́run ni èyí tí a bá lè jẹriì pé Qlọ́run tìkára rè̀ li ó sọ ố fún gbígbọ́ tàbí tí ó kọ ọ́ sílẹ fún kíkà àwa ènìyàn. Lệhìn èyí-Òoọ̀ Olộrun ni èyí tí ẹnikệni sọ, tàbí tí ó ko sílè, ìbá à șe nípa àșe tàbí nípa ìmísí Qlọ́run tìkárarè" ("God's genuine revelations are the ones for which we can testify truly that he either spoke directly to us or wrote them down for us to read. God's genuine revelations could also be those spoken or written down by those directly ordered or inspired by the Almighty to do so.")

The Godhead is the original writer and speaker who directly delivers his wishes in inscribed or spoken words. He could speak to favored listeners and dictate to chosen scribes who would then send forth the words. Either way, the medium-words, writing surfaces, or the inspired individual - must be touched directly by God in order for the message it bears to be valid.

Ifá divination protocols are the closest an "oral" society could devise to fulfill the requirement of genuinely divine writing and speaking, as Lijadu conceived them. Òrúnmìlà was co-present with the Almighty at the beginning of things. The divination God, skilled in inscriptions, reduces everything the Almighty has done to 256 symbols. Orúnmìlà does not create things. He only transcribes the Almighty's creations and designs. People trained to access Òrúnmilà's writing and speech portray him as capable of correcting ill-fated life directions ("atórí eeni tí kò sunwọ̀n șe"), not because he has possesses some mechanical re-engineering powers but because his exclusive knowledge of the transcriptions of the Godhead's intentions

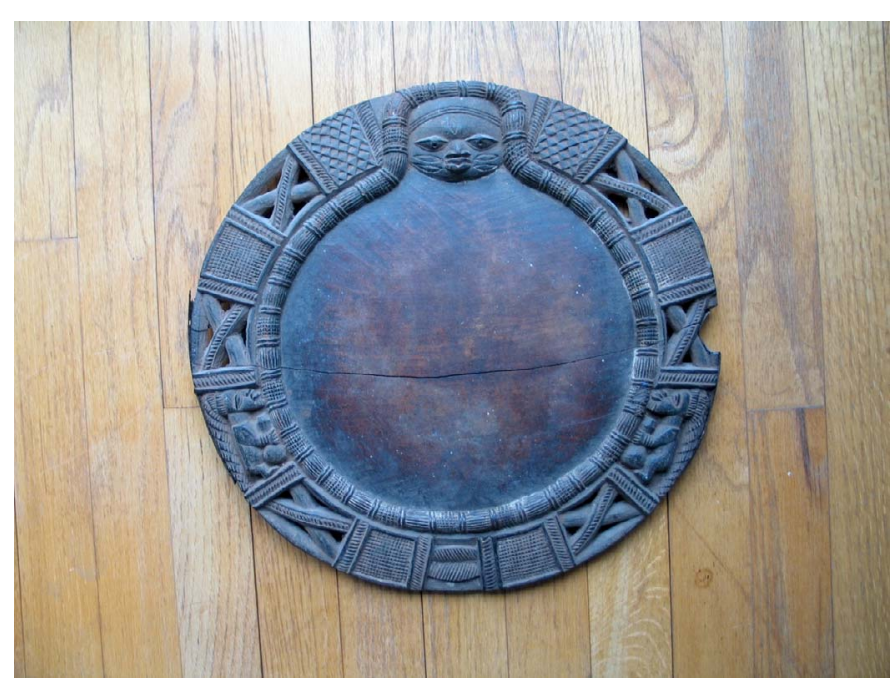

Divination tray. Photo by Henry Drewal, University of Wisconsin, Madison. can offer clues to the right path. I would like to speculate that Lijadu's very close studying of Ifá as a specimen of preChristian Yorùbá theology is based on the prominent role of direct writing in the disclosure system. Lijadu does not condemn Ifá as a system of direct divine revelation, probably because of its close ties to a minimally mediated writing system. He rejects Ifá because its storiesand not its graphic encoding-about God's true nature, true worship, true human nature, relationship to humans - do not quite agree with Biblical tenets. Lijadu is dissatisfied with Ifá teachings on human 
nature, especially regarding divine truth, the love of God and of fellow men and women, holiness, and the disinterested search for divine grace that are too lax and therefore unmeritorious in comparison to Christianity.

\section{Reference in Ifá}

Divination continues when the priest, having completed the transcription of the revealed sign and followed the set structure of the Ifá story unit ( $e s e)$, recites a narrative whose central motif addresses a situation similar in some respect to the predicament that the client seeks to resolve. All the stories pose a problem and a protagonist, usually in the form of an original client believed to be the person for whom the indicated story and inscription were first devised. The stories also construct at least one antagonist, a set of resolutions or an escalation, and the reaction of the entity who first addressed the problem (Abímbólá 1976:43-62; Bascom 1969:120-37; Ọlatunji 1984:127-34). Death (ikú), disease (àrùn), loss (òfo ), curse (èpè), paralysis (ègbà), general misfortune (òràn), incarceration (èzwòn), accidents (èșe), and witchcraft (àjé and oṣó) are the most common antagonists. These problems can afflict a person at will. One's enemies can also cause them through some diabolical machinations. Opposed to the antagonists are the dearly sought general blessings (ire) of wealth (owó), childbearing (omo), good health (àlàáfià), and longevity $\left(\grave{a} i k u^{\prime}\right)$. The antagonists represent forces of sickness or disease and protagonists those of health or well being. Control of the client's body and/or social existence triggers fighting between the two groups. The story unit (ese) has no independently verifiable embodiment in that it does not attach directly to one graphematic sign. In effect, the divined inscriptions generate stories, not phonemes. Ifá writing is mythographic rather than phonocentric. To quote Derrida (1976:85), it "spells its symbols pluri-dimensionally," and its referents are "not subject to successivity, to the order of a logical time, or to the irreversible temporality of sound."

T. M. Ilesanmi's schematic analysis of Ifá inscriptions and narratives reveals a deepseated binarism - "agbára méjì tó so ayé ró" ("the two poles on which existence subtends") (2004:132) - that Ifá diviners use to manage the "pluridimensional" significations of their writing method. According to Ilesanmi, ${ }^{6}$ Ifá priests ascribe positive, ire (good, desirable, well sought), values to some elements and negative, aburú (bad, undesirable, abhorred), values to others. They tie these values to the temporal order of appearance: the first to appear is the most positive and the next one less so; one notation is positive and two notations infer a negative. The sixteen primary figures of the odì are valued according to how the imprinted signs (ones and twos) and the ordinal rank of the presented odì (first, second, etc.) add up. Thus Ogbè, signed with all ones (and no two), is relentlessly positive (béẹ ni) and Òfún, all twos (and no ones), is frighteningly negative (béé kó). Although these two signs are ranked first and second in the ordinal system, they are actually polar opposites in the ideational scheme (134-35):

6 Ilesanmi is an ordained Catholic priest and professor of Yorùbá studies at the Obafemi Awolowo University, Ile-Ife. Three pioneering indigenous Ifá scholars, Phillips, Lijadu, and Johnson, were Anglican Church priests. 
Àwọn odù méjì yií ló ta ko ara wọn jù nínú àbùdá oníbejì beẹè-ni-bẹè̀-kó. Òkan kò ní bẹeè-kó rárá; èkejì kò sì ní bẹeè-ni olóókan. Kò sí ìgbà tí àwọn méjè̀jì jo wí ohun kan náà. Gbogbo àwọn odù yòókù ló ní beẹè-ni diệ, bẹèe-kọ diẹ nínú. Nínú ọ̀kan, ire le pò ju ibi lọ, nínú òmíràn, ibi le pò ju ire lọ. Wàyí o, ipò tí ibi àti ire wà ta ko ara wọn. Iye ire àti ibi kan náà ni Ėdí àti İwòrì ní șùgbọ́n wọ́n fi ipò ta ko ara wọ.

These two odù are polar opposites in the positive and negative binary structure. One has no negative at all; the other has not one positive. At no point do the two odì express the same attributes. All the other odù signs express a little of positive and negative values. In some, positives outnumber negatives; in others, negatives outnumber positives. The positioning of the attributes might oppose each other. Èdí and İwòrì express equal number of positives and negatives but in different positions.

Ilesanmi constructs two very useful charts of the signs, the first of which, reproduced below, depicts the ordinal sequence. In this table, "+" represents a positive value, while "-" stands for a negative.

\begin{tabular}{|c|c|c|}
\hline++++ & Ogbè & 1 \\
\hline---- & Oyèkú & 2 \\
\hline-++- & İwòrì & 3 \\
\hline+--+ & Èdí & 4 \\
\hline---+ & Òbàrà & 5 \\
\hline+--- & Òkànràn & 6 \\
\hline--++ & Ìrosùn & 7 \\
\hline++-- & Òwónnín & 8 \\
\hline-+++ & Ògúndá & 9 \\
\hline+++- & Òsá & 10 \\
\hline+-++ & Ìrètè & 11 \\
\hline++-+ & Òtúrá & 12 \\
\hline-+-- & Otúrúpòn & 13 \\
\hline--+- & Ìká & 14 \\
\hline-+-+ & Òsé & 15 \\
\hline+-+- & Òfún & 16 \\
\hline
\end{tabular}

Adapted from Ilesanmi 2004:135.

In this table, Òsé (15th) and Òfún (16th) have the same number of positive and negative attributes, but they are placed in opposite positions. Q̀sé opens with a negative, followed by positive, negative, positive in that order. Òfún unfolds in the inverse.

Ilesanmi argues that the assignment of values controls references in the odù inscriptions. He represents the "inner" oppositions of the odì system as adapted to the following tables: 


\begin{tabular}{|c|c|c|}
\hline++++ & Ogbè & 1 \\
\hline-+++ & Ògúndá & 3 \\
\hline+-++ & İrẹtẹ & 5 \\
\hline++-+ & Òtúrá & 7 \\
\hline--++ & Ìrosùn & 9 \\
\hline-+-+ & Òsé & 11 \\
\hline+--+ & Èdí & 13 \\
\hline---+ & Òbàrà & 15 \\
\hline+++- & Òsá & 16 \\
\hline-++- & Ìwòrì & 14 \\
\hline+-+- & Òfún & 12 \\
\hline++-- & Òwọnnín & 10 \\
\hline--+- & Ìká & 8 \\
\hline-+-- & Òtúrúpọ̀n & 6 \\
\hline+--- & Òkànràn & 4 \\
\hline---- & Òyẹkú & 2 \\
\hline
\end{tabular}

Adapted from Ilesanmi 2004:136.

Ilesanmi offers no speculation on why the public, outer, ordinal ranking differs from the inner order. Nor does he say why Ifá priests do not usually speak of the underlying binary with which they operate their system. The language of his conclusion suggests, however, that they might have been protecting their guild's secret: "méjì, méjì ni Ifá șe ìgbékalẹ èrò rẹ̀ lórí ayé; tibi-tire ló jọ ńrìn pò nínú ètò Ifá. Ìmọ̀ àbùdá oníbejì ló lè șí aṣo lójú eégun Ifá” (“Ifá’s central structure rests on a binary design in which positives and negatives walk hand in glove. Only the knowledge of how binary structures work can unmask Ifá") (146).

We should not forget that even the outer order that the priests present to the uninitiated is not universal. William Bascom recorded ten variations in Nigeria alone, eight in Benin and Togo, and two in Cuba. Moreover, the primary odù units do not carry any readable significance in practical, problem-solving divination until doubled or paired with another. This means that each consultation would involve ordering and decoding a minimum of thirty-two negative and positive values. A double Òfún, for example, would have to be arranged thus in the priest's mind; to the client, only the ordinal appearance - the two columns of ones and twos-is visible:

\begin{tabular}{|c|c|c|c|}
\hline \multicolumn{4}{|c|}{ Òfún Meji (Doubled Òfún) } \\
\hline $\begin{array}{c}\text { Ordinal Appearance Based on Ones } \\
\text { and Twos }\end{array}$ & $\begin{array}{c}\text { Inner Attributes Based on Negative } \\
\text { and Positive Values }\end{array}$ \\
\hline I (+) & I (+) & +-+- & +-+- \\
\hline II (-) & II (-) & +-+- & +-+- \\
\hline I (+) & I (+) & +-+- & +-+- \\
\hline II (-) & II (-) & +-+- & +-+- \\
\hline
\end{tabular}


Ilesanmi's sketch of the foundation of reference in Ifá's mythography is stimulating and absorbing. However, there is no evidence that the temporal order implied in the sequence of positives and negatives is repeated in the narrative plots of the illustrative stories (ese). That is, the imprinted signs do not appear to govern the story units. In order for Ilesanmi's "revelations" to work for practical criticism, we need to have an idea of how the values affect narrative sequence, the relation of plot details to the ordering of values, and so forth.

The only evidence I have seen for the possible plotting of thematic coordination with the imprinted signs in the stories occurs in the Epega and Neimark collection (1995). Stories in this volume demonstrate an inscription-governed thematic unity that one does not find in earlier published collections such as Bascom's (1969) or Abímbólá's (1969, 1977). Stories gathered under the Ògúndá sign, for example, reveal judicious adjudication to be Ògún's forte. In the narratives, Ògún, the God of iron, creates (dá) the path to being (ònà ìwà), and acts as the guarantor of biological reproduction and progeny (ișèdá). In the same manner, the resolution of Òsá stories generally upholds the literal glossing of the root word, sá, as having to do with fleeing for refuge. İká narratives also support the etymology of $k a ́$ in multiple references to encircling, circumscription, circumspection, reaping, bending, limiting, and so on. It is not clear to me whether the thematic unity of the Epega/Neimark stories reflects regional (İjèbú) variations or whether the coordination is a result of editorial selections guided by a more "literary" sensibility.

While future studies may reveal a closer relationship between the inscription details and the illustrative stories, such discovery will not diminish the importance of inscription for Ifá divination. Arriving at the right sign opens up channels of meaning-generation to diviners and clients. The client's whispering of his or her desires and concerns into the divination object brings the past of the client to the presence of the priest and the attention of the divination God's representative, the kernel or the chain, these being the main two divination instruments through which Òrúnmìlà's wishes are accessed. The inscriptions revealed by the objects present traces of the emblematic primordial events to which the divination God was a witness. The signs also instigate deliberations on what future actions the client should take. In this order of events, the generated inscriptions regulate the relation of the past, the present, and the future. The client's concerns and problems belong, like the divination God's archetypal knowledge, in the past; the priest's verbal articulation of such knowledge belongs in the present; realization of the agreedupon solutions derivable from the present interpretation of the divine codes belongs in the future.

The sample solutions modeled in the narrative have the chance to work if the client's disposition helps the process. Actionable reference, as the story unit or as the directive resulting from it, comes after the inscription; it belongs in the future of the "letter." Things could not be otherwise because the past (the "historical" referent) of the entity I am calling the letter, that is, the imprinted sign, belongs in the experience of the deity who witnessed creation at a moment that now lies permanently outside of immediate human cognition. This process reveals that Ifá practice distinguishes voice from graph without separating them; the "letter" does not correspond to a sound but to a stand-alone problem unit. Q̀rúnmìlà, the original writer, does not read his text verbally; the transcribing diviner (the deity's "writesperson") who can verbalize the contents of the inscriptions does not "write." He or she invents solutions, but these are not original to the diviner. 
The space and time left empty by a discontinuity between the systematic notations and the free-floating themes that they generate in stories invites commentary. In that location, "implicit significations" are teased out, "silent determinations" are made, and "obscured contents" are made manifest (Foucault 1979:145). The considerable time and intellectual expense that pioneer Yorùbá Christian missionaries devoted to that location is instructive. Believing that Ifá stories are theological as mentioned above, Lijadu found in the narratives evidence of admirable Godliness comparable with Christianity, but was exasperated by the sheer humanity of the Godhead - an entity who would not command a simple kola nut at will for his personal use and who fails to detect that one presented to him by a sacrifice carrier was picked up from a crossroads offering. Lijadu (1898:32) exclaims, "eleéyà ni gbogbo ìtàn yì̂” ("These stories are utterly contemptuous") because the Almighty they portray is not that mighty. "Irú Olódùmarè wo ni eyi e jàre!" ("What a puny God this is!"), he declaims. Karin Barber, a contemporary scholar, finds, for nontheological reasons, something untoward in how "Westernized members of the Yorùbá elite," including Lijadu, monumentalized Ifá by collecting, transcribing, and annotating the narratives recited by chosen priests, and then misrepresented the texts, perhaps unwittingly, "as a fixed body of knowledge" (1990:197). The elite allow themselves to be seduced by the built-in incorporation strategies of the Ifá discourse that cast its priest as someone who espouses a storied "body of wisdom conceived of as anterior and external to his own existence" (202), independent of his or her will. The only divination element that either Lijadu (the Christian, elite monument maker) or Barber comments on critically is the Ifá story's relationship to the inscription it supports. The written notations' anteriority to the priest's will, the client's wishes, and the story structure are never questioned. I would like to think that both Lijadu's project and Barber's critique are possible because the site of commentary-making is deliberately constructed and preserved in Ifá discourse so that the initiated and the uninitiated can interact over the meaning of the fundamental inscriptions of being.

\section{A Story of Origin}

A story that one of Wándé Abímbólá's informants associated with Ìwòrì Méjì, the sign that balances ones and twos on each side of the readable inscriptions, deals with the origin of the Ifá divination system (1969:34-40). (İwòrì pairs twos and ones symmetrically: two each on top and at the bottom and two ones between them. To use Ilesanmi's language, polar negatives are separated by two middle positives.) This story calls attention to itself as an autobiography of its own devices.

The story begins with the names of the four priests who coordinated the original consultation, two of whom are "Apá Níi Gbókoó Tan Iná Os ó" ("The mahogany bean tree takes to the bush to kindle its wizard red fire") and "Orúrù Ní Wệwù Ėjè Kalệ" ("The orúrù tree dons the blood red garment from top to bottom"). The third is named "Ilẹ́ Ni Mo Tẹ Tẹẹ Tẹ̀ Kí Ntóó Tọpón" ("For a long while did I cut ordinary earth before I began to cut divination tray sand"). The fourth is "Òpẹ̀ Tẹeẹeẹ Erékè Nií Yà sí Ya Búkà Mệrìndínlógún" ("The slender uphill palm tree divides into sixteen branches"). To reflect the tonal counterpoint principles that 
governed the poetic performance, Abímbólá breaks the names of the third and fourth diviners into two lines each:

Ilẹ́ ni mo tẹ tẹè tè

Kí ntóó tọpớn;

Òpè tẹéré erékè

Níi yà sí ya búkà mệrìndínlógún.
I cut the earth for a long while

Before cutting the divination tray sand;

The uphill slender palm tree

The one that divides into sixteen branches.

The four cast their objects and disclosed to Òrúnmìlà that he will be barren in Ifẹ̀. But their findings were mocked.

The ensuing narrative does not specify the odu inscription that indicates it, and the only authority we have that this is a story fitted for İwòrì is the priest who narrated it to the scholar. Abímbọlá does not identify which of Pópóo lá Àyìnlá (of İkòyí, near Ògbómọsọó), Oyèédélé İṣọlá (of $\mathrm{Be}$ e $\mathrm{s}$ in compound, Pààkòyí quarters, Òyó), and Adéjàre (of Pààkòyí quarters, Òyọ́) recited the story. But this cannot delay analysis. In practical terms, Òrúnmìlà's four diviners completed their brief after they relatred their findings. They could not have participated in the details contained in the rest of the story: logic dictates that its collation be attributed to succeeding observers and other diviners, including Abímbọ́lá's informants.

The story of the original diviners is not a simple one. According to Abímbólá, the named diviners led the first consultation session recounted in the story. He also adds that the names are either fragments of praise epithets (oriki) or pseudonyms (1977:19). The names, as such, historicize the narratives and make them accounts of something that actually happened. ${ }^{7}$ It is not hard to disagree with Abímbólá: if the priests existed in time and place, succeeding diviners who acknowledge their predecessors' activities do not seem interested in identifying them as historical figures. In a less literalistic viewpoint, diviners' names that are recited formulaically at the beginning of Ifá divination stories are tale-specific and are never repeated, even when the motif of events addressed in one story appears in another. Most often, the names summarize the topic of the events, which are represented in the consultation scenario. Abímbólá admits that the names could be personifications of animals or plants devised for narrative unity. This implies that the names are a story element, precisely a characterization strategy, and that they do not identify people whose lineage chants a listener can recite, or whose compound or hometown one can always locate precisely. From the beginning of the narrative, the names both hold together the activities of the coordinator(s) of an Ifá consultation and serve as a textual resource for brokering attribution. Invoking antecedence with the original priests' names helps to place the contemporary performer in a discursive line of descent.

The motif of the importance of patience for overcoming barrenness, the central theme of the İwòrì narrative under discussion here, permeates every facet of the story, including the names of the original diviners. The first diviner's name insinuates a paradox: the beautiful efflorescence of the hardy mahogany bean tree draws the attention of malevolent forces. Although the tough apá wood is very useful for building construction, its hardiness also attracts witches and wizards,

7 Bascom (1969) says that the only autochthonous sections of divination stories are the names of the diviners. Other parts could be sourced from folktales, myths, legends, and so on. 
who gather around it for their nightly deliberations (Abraham 1958). Ifá priests also use apá seeds as active ingredients in protective amulets. To name the second diviner, Abímbólá's informant pairs the scarlet flowers of the formidably tall orúrù tree with that of the apá to juxtapose threat and ultimate victory. The witches' malevolence has no effect on the trees' florescence. The victory theme is also present in the colorless, but forbearing, nature given to the other diviners. In time, it seems, the person who begins cutting divination signs on noticeably coarse soil will graduate to professional-grade fine sand on the divination tray; given time, the slender palm tree located in the tough uphill landscape shall bloom into sixteen full branches.

Events narrated in the next section of the story, lines 11-34, contradict the four wise diviners' prognostication, a development that shows divination's fallibility. Òrúnmìlà, contrary to predictions, has children who became kings all over, mainly in the provinces: Alárá, Ajerò, Qlộyé, Ońtagi, and Olộoọ. Alákégi and Elẹjẹlúmọ̀pé assumed the thrones of two territories that are not identifiable on a contemporary map. $\mathrm{O}$ wáràngún-àga became the leader of a diviners' guild. Further analysis of these names reveals more about the circumstances of their birth and the feelings of the parent who named them: Alárá (Companionship) colloquially translates as "I would make a companion of my child"; Ajerò (Communality) translates as "Children's causes warrant collective deliberations"; Olọyẹ (Harmattan) implies that having a child weathers the body. Others are identified by their father's professional activity at the time of the child's birth: woodcutting, wood-selling, and dye-making. According to their birth order, the older children represent the parents' youthful ambition, the middle four denote phases of material strivings for the sustenance of life, and the youngest two- $\mathrm{O}$ wáràngún and Olọ́wọ̀-commemorate the accomplishments of old age. The children's names signify different stages of the life span, from the search for companionship to respectful regard. Reproduction incurs more than procreation; it entails companionship, confronting the elements, physical work, participation in the exchange of goods and services, and rest.

The next section, consisting of thirty-five lines, further expands the meaning of reproduction to include the need for creating instruments for managing contacts and sustaining relationships. These lines describe how the father of the far-flung kings and master professionals maintains his extended family under central influence by instituting an annual pilgrimage to Ifẹ during the Ifá festival. On one such occasion, Olọwọ, the child imagined at birth as the symbol of respectful regard, shows up determined to publicly topple his authority. This person dresses up in a replica of the official outfit of Ifẹ̀'s chief diviner — then Òrúnmìlà — and refuses to pay proper homage. When asked to pay due respect, Olọwọ remains adamant. The confrontation is dramatized thus:

Ó ní òun ò lè páborúboyè bo șíṣẹ.

Òrúnmìlà ní èé ti jẹ?

Qlọ́wọ̀ ní ìwọ Òrúnmìlà sọ̀dùn kọ́, o sòdùn kọ́;

Òun Qlọ́wọ naa sọ̀dùn kọ́, òun sòdùn kọ́

İwo Q̀rúnmìlà fòsùn idẹ lọ́wọ́;

Òun Qlọ́wọ náà fòsùn idẹ lộwọ́

Ìwọ Q̀rúnmìlà bọ sálúbàtà idẹ;
He said he cannot wish him good tidings.

Òrúnmìlà asked why?

Qlộwọ̀ said you, Òrúnmìlà, are in raffia garments;

He the Qlộwò too dons raffia garments

You, Q̀rúnmìlà, carry a brass staff of office;

He the Qlówọ̀ too carries a brass staff of office

You, Q̀rúnmìlà, wear brass slippers; 
Òun Qlộwọ náà bọ sálúbàtà idẹ

Ìwọ Q̀rúnmìlà dádé,

Òun Qlọ́wọ náà dádé.

Bẹè̀ ni wọ́n sì ní

Ẹ̀nikan kìi forí adé balẹ̀ fẹ́nìkan.
He, Qlọwọ, wears brass slippers

You, Òrúnmìlà, wear a crown,

He, Olọ́wọ, has a crown on.

And it is known that

One crowned head does not prostrate to another.

A rival chief diviner exists now, the determined Qlọwọ̀ wants to say. The angry father, probably realizing the redundancy of his presence in the reflection mounted in Qlọwọ̀'s appearance, exiles himself into a tall, sixteen-branch palm tree.

It seems that Òrúnmìlà holds the key to some reproduction essentials because all motion on the cycle of life stopped after his departure: the pregnant could not deliver, the barren continued fruitless, the infirm remained bedridden, semen dried up in men, women ceased to menstruate, yams refused to grow, peas did not flower, chickens pecked at the few raindrops that fell, and goats mistook sharpened blades for yam peels and munched on them. The community sought divination help from unnamed diviners who prescribed for them what sacrifices to make and counseled them to assemble at the foot of the palm tree into which Òrúnmìlà had disappeared. As instructed, the people gathered around the tree and chanted the self-exiled priest's praise epithets, believing that they could coax him to return "home." But Òrúnmila stayed in exile and offered sixteen palm nuts as his proxy:

\author{
Q̀rúnmìlà ní òun ò tún relé mọ́ \\ Ó ní kí wọn ó tẹ́wọ́, \\ Ó wáá fún wọn ní ikin mệrìndínlógún. \\ Ó ní bẹ́ ẹ bá délé, \\ Bẹe ẹ bá fówóó ní, \\ Ẹni tẹé mọo bi nù un. \\ Bẹ ẹ bá délé \\ Bẹ ẹ bá fáyaá ní, \\ Ẹni tẹé mọo bi nù un. \\ Bẹe ẹ bá délé \\ Bẹ́ ẹ bá fớmọo bí \\ Ẹni tẹeé mọo bi nù un. \\ Ilé lẹ bá fẹeé kọ́ láyé, \\ Aṣo lẹ bá fẹeẹ ní láyé, \\ Ẹni tẹé mọo bi nù un. \\ Ire gbogbo tẹe ẹ bá fẹeé ní láyé, \\ Ẹni tẹé mọo bi nù un. \\ Ìgbà tí wọ́n délé, \\ Gbogbo ire náà ni wọ́n ńrí. \\ Òrúnmìlà afèdèfẹ̀yò̀,
}

Q̀rúnmìlà says he will never return home

He asked them to open their palms,

And handed to them 16 palm nuts.

He said, when you get home,

If you desire wealth,

That is the person to ask.

When you get home,

If you desire a wife,

That is the person to ask.

When you get home,

If you desire children,

That is the person to ask.

Should you want to build a home,

In case you want clothes,

That is the person to ask.

Any other comfort you might seek,

That is the person to ask.

When they got home,

All the blessings became theirs.

Òrúnmì̀à, the polyglot, 
Èlààsòdè

Ifá relé Olókun kò dé mọ́.

Ó lệni tẹe ẹ bá rí,

Ẹ șá mọo pè ni baba.
The redeeming deity of Ìsòdè

Ifá left for Olókun's abode.

He said whoever you see,

Call upon him.

The presentation of one divination as a function of an antecedent divination in this story reveals a characteristic of Ifá processes to which scholars do not usually pay attention: Ifá divination sessions are a consultation of a consultation. The first divination session in the foundational divination story concerns Òrúnmìlà's engagement with the four diviners and the details of the client's success in spite of contrary oracular predictions; the second divination session describes İfè people's failed attempt to bring Òrúnmìlà back from exile, a situation that arose because he could not manage his children; the third story, the one that presents the other two, is told by Abimbola's informants, probably as it was handed down to them from other diviners. The third story supplements the other two, one of which involves the birth of the discursive practice that governs all of the stories. All divination sessions involve the use of at least the first and the third types of stories, but only the first type is marked as a story because the diviner in charge of the present moment has to efface the importance of his or her own active material input. The babaláwo, as it were, has to spirit away his or her own presence by not marking the story of his storytelling. ${ }^{8}$

Ethnographic studies of Ifá will not suffice for analyzing this narrative of presence, absence, doubling, writing, appellating, conjuring, and responsiveness. The story describes the irremediably "occultic" nature of signification: the bare meaning that is embodied in what Orúnmìlà knows - details of the allotment of destiny—has permanently disappeared. Òrúnmìlà is never coming home with us! However, life continues in the exchange of traces of the instituted codes that bear fragments of Òrúnmìlà's record. Òrúnmìlà's permanent disappearance signifies that meaning, in itself, is gone. The search for recovery launched by the Ifẹ left behind in the material world shows that continued existence revolves around the anxiety of contingency. According to this narrative, the structure of the meaning production identified with Òrúnmìà construes being as the continuous coaxing from tokens of the unrecoverable past some useful means for approaching the present, which is in the future of that past.

That the story categorizes the reference of divination writing as material wellbeing in all its aspects (ire gbogbo), and more concretely as money (owó), spouse (aya), childbearing (omo ), shelter (ilé), and clothing (aṣo) is significant. The authority (or spirit) that controls the knowledge of the distribution, use, and acquisition of these blessings, none other than the eyewitness to creation, cannot be accessed directly, but rather through its occult proxies, which in practice exist as a structure of appellation; "eni té mọo bi nù un" ("that is the person to ask"), the oracle instructs. The permanently absent Q̀rúnmilà offers the palm nuts (and the inscriptions generated through them) as his principle of "being-there." Operators of the divination

8 Òrúnmìlà here institutes a system of iteration: "the possibility for every mark to be repeated and still to function as a meaning mark in new contexts that are cut off entirely from the original context, the "intention to communicate' of the original maker of the mark. That originator may be absent or dead, but the mark still functions, just as it goes on functioning after the death of its intended recipient” (Miller 2001:78). 
infrastructure endeavor to ensure that the palm nuts accurately transmit the spirit's reply to their labors of inquiry.

In the calculus of material existence worked out in this story, the spirit is in permanent exile; it cannot return home. This spirit's irreversible alienation, as well as the trace forms in which it partially appears when properly invoked, a good part of which is the story unit, are essential for the procreation of life in general. The palm nuts, the remainders, constitute the "masque" of the spirit that has become un-present-able. ${ }^{9}$ The spirit mitigates the effect of its absence with the mute palm nuts, the signs of its absent-presence. The inscripted signs transcribe patterns of the knowledge Òrúnmilà gained as a result of his one-time presence at the time of destiny. The divination narrative connects and translates the significance of the traced-out presence (which is a sign of an irremediable absence) as stories to be interpreted for the present moment, with the collaboration of the client who is seeking insights, into a fragment of general existential difficulty.

In theory, reference in Ifá discourse approximates what Òrúnmìlà witnessed at the distribution of destiny. ${ }^{10}$ Divination therefore involves probing into the inner reaches of essential occultation (awo) for the main purpose of making it yield fundamental knowledge (imọ) about life. Divination hermeneutics as instituted in Ifá practices requires effort to draw plain knowledge out of the hidden or occulted. Stories are used to translate inscripted codes of Òrúnmilà because the record of the events witnessed at the distribution of destiny cannot travel as events any more. Those events happened only once; even if Òrúnmìlà did not disappear into the palm tree, he can only relate narrativized versions of what he witnessed. Events survive beyond happenstance only in stories, or itàn.

The İwòrì Méjì story shows that several translations occur between the priest's transcription of the signs indicated by the nuts and the client's response to counseling. Òrúnmilà's four priests probably recited a narrative whose contents Abímbọlá's informants summarized in one line about barrenness. Òrúnmilà's curt reaction to the diviners' conclusion indicates that while clients can follow their own will, priests are not free to do as they wish and must be guided by the inscription-story. After interpretation, priests can conclude their brief and depart, while the clients begin to exercise their intelligence and will. Òrúnmìlà laughs off his counselors and ends up inside a palm tree!

\section{The Past and Present in Ifá Writing}

Early Yorùbá Christian clergymen believed that divination priests led an "oracular cult" that made "hegemonic claims to a special relationship with the Supreme Being, with a key theme

${ }^{9}$ It should not be forgotten that the odù writing practice is literally operated by remainders; in the palm nut divination system, for example, only remainders express portentous inscription. I have borrowed the idea of the spectral relationship of "masque" to "spirit" from Derrida 1994.

${ }^{10}$ Ipín (literally, "allotment" or "destiny” in colloquial Yorùbá) is what Q̀rúnmìlà reveals through (and in) the divination process. But in practical divination terms, ipin is what recurs in narrativity. The divination story contains what has happened at least once in the past. 
- the powerful precedent - that presents a highly refracted memory of the vanished greatness of its sacred centre" (Peel 1990:344). The pastors invested much interest in the diviners, as I observed earlier, because the latter held sway over the non-Christian population mainly through the mystique of their graphematic practice. Befriending and converting powerful local divination priests netted for the Christians not an individual pagan but a "truth regime" leader, as it were. Converting a divination priest brings the pagan mythography under the authority of a phoneticized and allegedly more democratic writing system. At least, that is what Bishop Phillips believed. The missionaries did not attack the mythography. Instead, they exploited the commentary-making space, the space between inscription and action, to discredit the divination priests as selfish charlatans who used the mystical basis of their technique to do just as they wished and mislead their clients. In the words of Rev. Lijadu (1898:66):

\footnotetext{
Lára jíjẹ àti mímu ni olóri aájò àwọn babaláwo kulẹ sí; níbẹ kan náà ni ti àwọn olùsìn tìkárawọn náà mọ pẹ̀lú. Síbẹ̀síbẹ a wá ọ̀pọ̀lọpò ìtàn asán jọ láti já àwọn ògbẹ̀rì lí àyà tàbí láti yá wọn lórí, tàbí láti fo àwọn adẹjàá lí eyẹ, kí wọon má șe lè șe orùn líle, ṣùgbọ́n kí wọ́n fi ohùn sí ibi tí àwọn babalawó bá fí i sí.
}

\begin{abstract}
Subsistence interest is the be-all and end-all of divination priests; the same goes for their followers, too. Jejune tales are gathered to either scare or enthuse the uninitiated or to mislead the inquisitive so that they will cease asking questions and agree with the priests' self-serving conclusions.
\end{abstract}

Lijadu addresses more than theological facts here. He construes the use of narratives in Ifá divination as a barefaced "presentism," that is, a system by which divination priests construct the past to suit only today's needs. The divination priest's claims for the past cannot be verified.

Karin Barber works only with post-inscription elements of the divination process, showing how Ifá discourse incorporates other discourses into its processes in order to position itself strategically as the governor of the Yorùbá intellectual universe. As noted above, Barber also does not question the consistency of the inscriptions. Her concern is with how the priests' stories use verifiable "techniques of argument" to place Ifá above all else. The strategies include "narrative positioning," that is, the unrestrained thematic range of the contents of divination stories authorizes diviners to appropriate tales from all sources, all domains, and about any topic, consign them to the past, and then retrieve the same as ideas activated by the revealed imprinted sign. Barber characterizes Ifá's "narrative positioning" in words similar to Lijadu's: "The 'moral' is always the same, whatever the origin of the story: 'Ifá knows best . . . Do what Ifá tells you and you will prosper; disobey Ifá and disaster will ensue"” (1990:208). Another incorporation strategy that Ifá uses is "preempting time": the problems addressed in each story report an event as having taken place in the distant past, and the diviner comments on the events as if Òrúnmì̀ constructed and handed down a model of future action from patterns observed in the past. The cleverest part of the presentation of Ifá's all-encompassing model, Barber says, is that the divination God himself appears as a bewildered client in many of the stories: "Ifá the deity himself appeals to a body of wisdom, encoded in precedents, which must be seen as outside his consciousness and antecedent to him. Nothing can go behind this paradox: the argument of 
the precedent is arrested at that point in a permanent and unresolvable deadlock. This has the effect of enhancing the authority both of Ifá as system and as spiritual being" (209). Ifá's third main discourse-making technique is "lexical layering," or the invention "of strange names" for familiar acts and objects. For example, Ifá stories commonly refer to the mouth as "olúbọ́bọtiribó baba ębo" ("the insatiable devourer of all sacrificial offerings").

Barber evaluates Ifá stories in the way we currently think of histories as reports of past events in proportions narratively scaled to reflect how persons interacted among themselves and with their environment in verifiable, specified spaces and time. But this model of the past would apply to Ifá divination stories only if the graphic notation stage of the divination process were treated as an extraneous element with no significance at all. To refer back to the reading proposed above, Barber neglects the significance of the mythographic inscriptions that stand for the permanent barrier to our capturing past events in their "true" proportions. The commentary space in Ifá divination protocols would also have to be completely disregarded in order for the "presentism" criticism to be fully accepted. But we cannot speak about Ifá discourse or extract significance from its practices without considering "writing" and "commentary." The central axiom of Ifá practice that enjoins critical listening and acting on the client was recorded by Lijadu himself: "Bí o bá tệfá tań, kí o tún 'yè rẹ tẹ̀" ("When you're done consulting Ifá, be sure to re-consult your gumption") (1898:37). A person counseled in Ifá is duty-bound to re-counsel him or herself and decide to what extent instructions and prescriptions should be followedÒrúnmilà mocked his diviners in the story discussed above. The self-re-counseling injunction means that every story unit gives an allegorical account of how things were and how similar they might be in the present, although not in mimetic proportions. The priest's retelling must generate a directive, evince a pledge, articulate a feeling, or change the status quo (Searle 1979), all gestures of àtúntè (re-imprinting, re-counseling). In other words, the divination client is not expected to make the present as it was. Even Òrúnmìlà could not perform such a feat. As records of divination sessions show, the priest and the client, voluble readers of Ifá's mute signs in the commentary space, are not absolved from the responsibility of contemplation and self-reflection. Although the solutions to the problems presented by Ifá divination clients might have been "authored" by precedence, stories told to articulate antecedent transactions are not therefore exempted from answering to genuinely new responsibilities.

Ifá narratives are not like simple, constative, or descriptive charters whose primary referential relationship is to an event, a moral goal, or the performer's other vested interests. In the divination story, convention-bound as it is, the narrator-priest, in theory, is obliged not to pursue a detectable personal interest - except that of proving to be a competent, honest broker of the revelations of destiny - in the problem addressed by the story. For this reason, I would suggest, the referential antecedence of the Ifá story is the inscription and not the event of the story, which, in theory, only the disappeared Òrúnmilà experienced. The "letters" that signify the story do not proceed from the priest's will but from the divination instrument, that is, the palm nuts (or the chain). Ifá clients do not just seek a reading; they are best served only when the "writing" is done correctly.

How does Ifá practice actualize a theory of time and history and elaborate how the past influences (or does not influence) the present and the future? In Ifa Divination Poetry (1977:20), 
Abímbólá asserts that the divination story “is a type of 'historical' poetry.” J. D. Y. Peel offers a more nuanced explanation (1984:113):

Every poem of Ifa is an attempt to narrate, through the peculiar structure of Ifa divination poetry, things which the Ifa priest has been taught to believe actually happened in the past. By narrating these stories of the past, the Ifa priest believes that his client can then pick situations similar to his own and advise himself of the best thing to do in the light of the precedent which has been cited for him.

The Ifá system liberates clients from the tyranny of the past by giving them the chance to negotiate a change they can live with: "present practice is governed by the model of past practice and, where change does occur, there is a tendency to rework the past so as to make it appear that past practice has governed present practice" (113). I would emend Peel and say that the expectation that the client should act willfully upon the reports of the events presented by the diviner demonstrates that the stories constitute - and not just report - the events. The client can forestall the portentous past from repeating itself or allow it to fulfill its propitious potential. In Ifá, the fact that the past is in exile does not mean that the present stands alone. The past is not the present of the living client, who still has to make the labor of sacrifice. That sacrifices and offertories (ebo ) made in the past do not offer protections against present and future peril represents a clear notion of how the past differs from the present. Living clients are responsible for their ebo, which are made not to the past but in the present for the smoothing of yet to be trodden paths. Were Ifá stories merely constatives of past events, no new narratives would be possible. But Ifá stories recount the basis of belief in Islam, explain the peculiarities of Christian beliefs, and even divine the significance of the coming of railways, all of which are historical developments that came about after the disappearance of Òrúnmìà into the palm tree. That is why I conclude that in Ifá practice the inscription system physically marks what Peel calls the "otherness of the past" and authorizes the relative autonomy of commentary in the form of storytelling (1984:127).

Ohio State University

\section{References}

Abímbọ́lá 1969

Abímbọ́lá 1976

Abímbọ́lá 1977
Wánde Abímbọ́lá. İjìlè Ohùn Enu Ifa-Ápá Kejì: Àwọn Ifá Ǹláńlá. Glasgow: William Collins.

Ifá: An Exposition of Ifá Literary Corpus. Ibadan: Oxford University Press.

. Ifa Divination Poetry. New York: Nok. 
Abraham 1958

Austin 1962

Barber 1990

Bascom 1961

Bascom 1969

Derrida 1976

Derrida 1994

Epega 1987

Epega and Neimark 1995

Foucault 1979

Ilesanmi 2004

Johnson 1899

Lijadu 1898

Lijadu 1908

Miller 2001
R. C. Abraham. Dictionary of Modern Yoruba. London: University of London Press.

J. L. Austin. How to Do Things with Words. Ed. by J. O. Urmson and Marian Sbisà. Cambridge, MA: Harvard University Press.

Karin Barber. "Discursive Strategies in the Texts of Ifá and in the 'Holy Book of Odù' of the African Church of Òrúnmìlà." In Self Assertion and Brokerage: Early Cultural Nationalism in West Africa. Ed. by P. F. De Moraes and Karin Barber. Birmingham: Center for West African Studies, University of Birmingham. pp. 196-224.

William Bascom. "Odu Ifa: The Order of the Figures of Ifa." Bulletin de l'Institut Français d'Afrique Noire, 23:676-82. . Ifa Divination: Communication Between Gods and Men in West Africa. Bloomington: Indiana University Press.

Jacques Derrida. Of Grammatology. Trans. by Gayatri Chakravorty Spivak. Baltimore: Johns Hopkins University Press. Specters of Marx: The State of the Debt, the Work of Mourning, and the New International. Trans. by Peggy Kamuf. New York: Routledge.

Afolabi A. Epega. Ifa: The Ancient Wisdom. New York: Imole Oluwa Institute. and Philip J. Neimark. The Sacred Ifa Oracle. San Francisco: Harper.

Michel Foucault. "What is an Author?" In Textual Strategies: Perspectives in Post-Structuralist Criticism. Ed. by Josué V. Harari. Ithaca: Cornell University Press. pp. 141-60.

T. M. Ilesanmi. Yorùbá Orature and Literature: A Cultural Analysis. Ile-Ife: Obafemi Awolowo University Press.

James Johnson. Yoruba Heathenism. Exeter: James Townsend and Son.

E. M. Lijadu. Ifá: Imole Rẹ ti i Șe Ipile Isin ni Ile Yoruba. Rpt. 1972. Ado-Ekiti: Omolayo Standard Press. . Òrúnmilà Nipa. Rpt. 1972. Ado-Ekiti: Omolayo Standard Press.

J. Hillis Miller. Speech Acts in Literature. Stanford: Stanford University Press. 
O latunji 1984

Peel 1984

Peel 1990

Searle 1979
O latunde O latunji. Features of Yorùbá Oral Poetry. Ibadan: University Press.

J. D. Y. Peel. "The Past in the Ijesha Present." Man, n.s. 19:111-32.

. "The Pastor and the Babalawo: The Interaction of Religions in Nineteenth Century Yorubaland." Africa, 60:338-69.

John R. Searle. Expression and Meaning: Studies in the Theory of Speech Acts. Cambridge: Cambridge University Press. 
This page is intentionally left blank. 